\title{
THE EFFICIENCY OF THE NON-SPECIFIC TENNIS MEANS OF PREPARATION AT JUNIOR PUBERTY AGE UNDER 13 - 14 YEARS LEVEL
}

\author{
Corneliu SCURT ${ }^{*}$ \\ cornelscurt@yahoo.com \\ Transilvania Universityof Brașov
}

\begin{abstract}
:
The research hypothesis starts from the premise that the use of some operational structures can be converted into well-structured training programs, by increasing the volume of the technicaltactical acquisitions applied at the training level of puberty players during training and matches. The purpose of the research is to continuously improve and guide the content of the training, by including the non-specific means in tennis playing. The topic of the research is represented by the methods and means of training as well as by the structure of the competitive calendar by restructuring the training with the introduction of the non-specific means in tennis playing. The practical value of the research is given by the possibility to elaborate training models that include some non-specific means in tennis playing.
\end{abstract}

Key-words: puberty, tennis, non-specific means

\section{Introduction}

The process of growth and development continues till the age of puberty. During this period some processes become more resistant, they increase in length in order to make possible some processes that require a certain level of motor qualities (Baciu, A., M, 2008). The osteo-articular apparatus is poorly developed, thus, its tensile strength being low (Demeter, 1984).

The biological parameters of secondary selection add to the psychic profile: intelligence, speed of reaction, spirit of anticipation, resistance to stress and tiredness, the ability to focus and maintain it (Drăgan, I. 1989).

The physical profile: height, large arm span, strong lower limbs, explosive force, large biacromial diameter. The metabolic support is aerobic (Ifrim., M. 1989).

The formation of ball hitting skills as well as the specific tactical rules require special efforts from both the coach and the athlete (Baciu, 2008).

Learning will begin at an early age (Catanescu, C., 2010). The optimal age for tennis debut is 8-9 years (Crăciun, M., 2009).

In echeloning the task of learning and in perfecting the technique and tactics, the requirements of the competitive game will be taken into account (Crăciun M, 2009).

It is a sport in which the qualities of speed with the variants prevail: the reaction, execution, and movement speed, endurance, general and specific coordination, balance, strength, synchronization of movements, focus, anticipation, intelligence that should help him (Bompa., T. , 2003) (Segrceanu, A., 1986)

The learning and improvement of tennis is approached in a certain succession: right lift, left lift, service. (Segarceanu., A., 1989)

The lack of skills or defective skills can be compensated by personality traits such as motor skills, motor attitudes (Colibaba, E.D. 1989).

It is considered that the use of some operational structures for each element and technical-tactical procedure specific to the age of 13-14 years will be converted into well-structured physical 
training programs increasing the volume of technical-tactical acquisitions applied during training and matches (Segarceanu, A., 1989).

\section{Material and method}

The training program was designed for a team of girls aged 13-14 from the Olimpia club in Braşov between April 1 ${ }^{\text {st }}, 2018$ and June 31 $1^{\text {st }}, 2019$.

The program includes percentile masses on the Standard fitness test battery which evaluates the level of general fitness, by introducing new tests and by modifying the existing ones: $50 \mathrm{~m}$ speed running, long jump from the spot, endurance running, throwing the oina ball at a distance, hanging on a fixed bar with folded arms, 10 X5m back and forth running, lying on the back lifts.

We have opted for the tests that are recommended at this age: $10 \times 5 \mathrm{~m}$ back and forth running, long jump from the spot, lying on the back lifts, hip mobility in the foreground and endurance running.

In addition to the motor tests, the battery of tests also includes measurements of anthropometric indicators and identification data of those tested:

- $30 \mathrm{~m}$ speed running,

- $50 \mathrm{~m}$ speed running,

- endurance running,

- pushups,

- $10 \mathrm{~m}$ running with your knees up and continuing to accelerate

- direction change running

The statistical-mathematical indicators obtained by measurement were: - the arithmetic average, the standard deviation and the amplitude.

The determination of the level of the capacities, factors and evaluation tools was carried out by measurement, throughout the research as follows:

- softiness $/$ mobility $=$ stretching hands while sitting

(T 1.) the highest value is recorded at the subject $2=12 \mathrm{~cm}$, while the minimum value is recorded at $(\mathrm{T} 2)=12 \mathrm{~cm}$.

the explosive force of the lower limbs = long jump from the spot, maximum values $(\mathrm{T} 1=$ $190 \mathrm{~cm})$ at the first test and (T.1) at the second test, the arithmetic average being higher when tested second time.

- the abdominal muscle strength and endurance $=$ repeated lifting of the torso in lying position, the values

- The muscle strength and endurance at the level of the arms and shoulders = by keeping the arms bent at the fixed hanging bar, the differences between the two tests being $1-2 \mathrm{~cm}$.

- moving speed $/$ the speed $=$ back and forth running speed $10 \times 5 \mathrm{~m},(50 \mathrm{~m})$

- cardio-respiratory resistance $=24 \times 20 \mathrm{~m}(480 \mathrm{~m})$ back and forth running has a modest measurement value for running time without running around the milestone every $20 \mathrm{~m}$.

\begin{tabular}{|c|l|l|l|l|l|c|c|}
\hline NO & SN & SEX & \multicolumn{1}{l|}{ AGE } & \multicolumn{3}{|l|}{ ANTHROPOMETRIC } & ADIPOSE \\
DATA & TISSUE \\
\hline CRT & & & & H & W & GDB & mm \\
\hline 1 & BD & F & 13 & 137 & 35 & 18.91 & 42 \\
\hline 2 & RA & F & 13 & 136 & 37 & 20.10 & 40 \\
\hline 3 & CC & F & 14 & 140 & 39 & 19.87 & 36 \\
\hline 4 & MB & F & 14 & 142 & 42 & 2089 & 38 \\
\hline
\end{tabular}

Table 1. Tested subjects anthropometric 
We note that height and weight have values consistent with the GDB $=18-24.9$ values with minimal health risk.

\begin{tabular}{|c|c|c|c|}
\hline \multirow[t]{3}{*}{ Identification data } & \multicolumn{3}{|l|}{ Surname Name } \\
\hline & \multicolumn{2}{|l|}{ Age (years, months) } & \\
\hline & \multicolumn{2}{|l|}{$\operatorname{Sex}(m / f)$} & \\
\hline \multirow[t]{3}{*}{ Anthropometric measures } & \multicolumn{2}{|l|}{ waist $(\mathrm{cm})$} & \\
\hline & \multicolumn{2}{|l|}{ weight $(\mathrm{kg})$} & \\
\hline & \multicolumn{2}{|c|}{$\begin{array}{l}\text { Body fat, five skin folds: biceps, } \\
\text { triceps, subscapular, malleolar } \\
\text { suprailiac (mm). }\end{array}$} & \\
\hline $\begin{array}{l}\text { Evaluated dimension } \\
\text { capacities / competencies }\end{array}$ & Factor & \multicolumn{2}{|c|}{$\begin{array}{l}\text { Test } \\
\text { Evaluation tools }\end{array}$} \\
\hline $\begin{array}{l}\text { Cardio-respiratory } \\
\text { resistance }\end{array}$ & $\begin{array}{l}\text { Cardio-respiratory } \\
\text { resistance }\end{array}$ & \multicolumn{2}{|c|}{$\begin{array}{l}\text { Resistance back and forth run } \\
(\mathrm{min} / \mathrm{sec}) 24 \mathrm{X} 20 \mathrm{~m} . \\
\text { Test on the exercise bike }(\mathrm{min} / \mathrm{sec})\end{array}$} \\
\hline Force & Explosive force & \multicolumn{2}{|c|}{ Long jump without momentum $(\mathrm{cm})$} \\
\hline \multirow[t]{2}{*}{ Muscle endurance } & Functional force & \multicolumn{2}{|c|}{ Bent arm suspension $(\mathrm{sec})$, } \\
\hline & Torso strength & \multicolumn{2}{|c|}{ Lying lifts (no/30sec), } \\
\hline Speed & Coordination speed & \multicolumn{2}{|c|}{ Back and forth run $10 \times 5 \mathrm{~m}(\mathrm{sec})$} \\
\hline Suppleness & Suppleness & \multicolumn{2}{|c|}{$\begin{array}{l}\text { Forward flexion of the torso, } \\
\text { in a sitting position }(\mathrm{cm})\end{array}$} \\
\hline
\end{tabular}

Table 2. Identification data of the anthropometric measures and of the assessment tools

\begin{tabular}{|c|c|c|c|c|c|c|c|c|c|c|c|c|}
\hline & \multicolumn{2}{|c|}{$\begin{array}{l}\text { Forward } \\
\text { flexion of } \\
\text { the torso, } \\
\text { in a sitting } \\
\text { position } \\
(\mathrm{cm})\end{array}$} & \multicolumn{2}{|c|}{$\begin{array}{l}\text { Long jump } \\
\text { without } \\
\text { momentum } \\
(\mathrm{cm})\end{array}$} & \multicolumn{2}{|c|}{$\begin{array}{c}\text { Back lying } \\
\text { torso lifting } \\
\text { (nr/30sec) }\end{array}$} & \multicolumn{2}{|c|}{$\begin{array}{l}\text { Bent arm } \\
\text { hanging } \\
(\mathrm{min} / \mathrm{sec})\end{array}$} & \multicolumn{2}{|c|}{$\begin{array}{c}\text { Back and } \\
\text { forth run } \\
10 X 5 \mathrm{~m} \\
(\mathrm{~min} / \mathrm{sec})\end{array}$} & \multicolumn{2}{|c|}{$\begin{array}{l}\text { Back and } \\
\text { forth run } \\
24 X 20 \mathrm{~m} \\
(\mathrm{~min} / \mathrm{sec})\end{array}$} \\
\hline B.D & 8 & 10 & 190 & 195 & 32 & 33 & $30 \mathrm{sec}$ & 40 & 13.5 & 13.3 & 2.45 & 2.35 \\
\hline$R . A$ & 9 & 12 & 185 & 195 & 30 & 32 & $20 \mathrm{sec}$ & 25 & 12.9 & 12.7 & 2.30 & 2.20 \\
\hline C.C & 7 & 9 & 180 & 190 & 31 & 33 & $15 \mathrm{sec}$ & 25 & 12.5 & 12.3 & 2.58 & 2.45 \\
\hline$M B$ & 5 & 8 & 180 & 1.75 & 35 & 36 & $38 \mathrm{sec}$ & 50 & 12.4 & 12.2 & 2.40 & 2.35 \\
\hline & $R 1$ & $R 2$ & $R 1$ & $R 2$ & $R 1$ & $R 2$ & $R I$ & $R 2$ & $R l$ & $R 2$ & $R 1$ & $R 2$ \\
\hline$X^{-}$ & 7.25 & 9.75 & 183.75 & 188,7 & 32 & 33.5 & 25.75 & 35 & 12.87 & 12.6 & 2.42 & 2.33 \\
\hline$\sigma$ & 0.97 & 1.94 & 4.85 & 9.7 & 25.24 & 1.94 & 20.87 & 44.9 & 0.53 & 0.53 & 13.59 & 12.13 \\
\hline$W$ & 4 & 4 & 10 & 20 & 5 & 3 & 28 & 12.13 & 1.1 & 0.53 & 28 & 12.13 \\
\hline
\end{tabular}

Table 3. Performed test results.

\section{Research results}

- as for the research results an increased level of values both at the level of the first test and the second test is noticed.

- forward flexion of the torso has higher values at the second test for all sportswomen, compared to the first test where the arithmetic mean is $7.25 \mathrm{~cm}$ significantly lower than the average result from the second test $9.75 \mathrm{~cm}$ (Table 3) 
- as for the long jump without momentum, the values of the indicators for the first two sportswomen are $1.95 \mathrm{~m}$ with an arithmetic average of $1.95 \mathrm{~m}$, while the lifting of the torso from back lying in $30 \mathrm{sec}$ have insignificant values.

- bent arm hanging has the highest value of $50 / \mathrm{sec}$ and $40 \mathrm{sec}$.

- the $10 \mathrm{X} 5 \mathrm{~m}$ back and forth run has the role of coordinating the body in alternating effort the endurance $24 \mathrm{X} 20$ back and forth run can also be done outdoors due to the lack of a properly arranged room.

\section{Conclusions}

The use in training and competitions of some means that are used in the form of non-specific structures, which converted into training programs, increase the volume of acquisitions at the level of 13-14 year old juniors.

The absence of a unitary conception with reference to the way to carry out the promotion a higher value level.

We opted for the tests that are recommended at this age and along with the motor tests they successfully cope with training and competitions.

\section{Recommendations}

The inventory of the operational structures used at the age of 13-14 years old, meant to improve the execution technique when training and in competitions.

The use of non-specific means as training means.

When training the motor experience of athletes should be taken into account.

\section{References}

1. Alexe, N., \& all. 1993. Antrenamentul sportiv modern. Ed. Editis.

2. Baciu, A. 2008. A ntrenamentul în tenisul de câmp, Cluj Napoca: Napoca Star.

3. Bompa, T. 2003. Totul despre pregătirea marilor campioni, Ex. Ponto.

4. Cătănescu, C. 2010. Programe operaționale de instruire la jocul tenis. Universitaria Craiova.

5. Colibaba, E. \& Bota, D. 1998. Jocuri sportive. Teoria și metodică. Bucuresti: Editura Aldin.

6. Demeter, A. 1974. Bazele fiziologice ale formării deprinderilor motrice. Bucuresti.

7. Epuran, M. \& Horghidan, V. Psihologia Educatiei fizice, Ed. ANEFS, 19.

8. Ifrim, M. 1986. Selectia și orientarea medico sportivă, Bucuresti: Editura Sport-Turism.

9. Richard, S. 1993. Să-i învăţăm corect la mare performanţă. Ed. Helicon;

10. Segărceanu, A. 1986. Tenis-Tehnica, Tactica, și Metodica, Bucuresti: Editura Qasar. 